\title{
The situation in Albania concerning labour relations, employment policies and perspectives
}

\begin{abstract}
The Republic of Albania is situated in the south-east of Europe, covering a territory of 28748 square $\mathrm{km}$ and with a population of 3170 048. The transition from a centralised economy to one based on the free market has proven challenging, as successive governments have tried to deal with high unemployment, widespread corruption, a decaying physical infrastructure and widespread social problems, especially in rural areas. Albania's economy continues to grow, but the country is still one of the poorest in Europe, hampered by a large informal economy and an inadequate energy and transport infrastructure. Furthermore, the most recent EU progress report indicates that there has been little progress in the field of social policies. Poverty is $66 \%$ higher in rural areas than in Tiranë and $50 \%$ higher in rural areas than in other major urban centres. Albania has been a potential candidate for accession to the European Union since January 2003, and it formally applied for EU membership on 28 April 2009.
\end{abstract}

Keywords: unemployment, equality, education, occupational training, informal economy, active and passive labour policies, public employment services, social dialogue, migration, returning migrants

\section{Labour market situation}

Employment rates

The development of the labour market and the encouragement of employment constitute one of the main components of state policies for raising the level of employment and, consequently, reducing poverty in Albania. The National Strategy for Employment and Professional Training has set out concrete and realistic objectives for the development of the labour market, the improvement of the quality of the employment services, the application of contemporary standards and orientations, and involving labour market job-seekers.

\section{Unemployment rates}

The official unemployment rate for 2009 was 142275 people, or $12.9 \%$ of the workforce. 71935 of the unemployed were women; 92126 were long-term unemployed; 88585 benefited from economic assistance; 9832 benefited from unemployment allowance; and 8921 were from specific groups.

The unemployment level has been higher for women than for men during the transition period. The difference in the scale of unemployment between men and women was more noticeable in urban areas than rural ones. 
The level of unemployment is higher in the north-eastern part of the country, which has not been able to recover economic activities lost after the 90s. The area has not been able to offer potential for local businesses to invest and develop their investments, while the infrastructure of the area is poor and there has been a lack of movement of habitants in neighbouring counties in the south and centre of the country. Additionally, it has been noted that the business community has been attracted more by the cities than by the areas around them because in urban areas they have greater possibilities for success. According to government statistical data, unemployment in 2006 was $24.6 \%$ in the north, compared to $13.3 \%$ in central areas and $13.5 \%$ in the south. There is no official database or information subsequent to 2006 on the demography of employment or unemployment.

Unemployment according to level of education shows that $54.6 \%$ have finished elementary education (up to $8^{\text {th }}$ grade - the system has been changed to nine grades after 2010), while $43.6 \%$ have finished high school and only $1.8 \%$ have a university degree.

The Labour Force Survey for 2007-2008 shows that the unemployment rate for young people between 15-24 years was $27.2 \%$, while young people amount to $27.8 \%$ of the total number of unemployed people. These figures show that young people are facing many difficulties in finding a job on the labour market; indeed, the chances of a young person finding a job are 2.5 times lower than those of an adult. This is a major difference which shows that the creation of new jobs for young people is lower than it is for adults.

If we analyse entrance and exit from unemployment, we see that unemployed people without any profession comprise $32 \%$ of the total number; unemployed workers who have no special skills comprise $47 \%$; while only $18 \%$ of the registered unemployed have intermediate skills in fields such as the clothing industry, building and carpentry. Unemployed people with a university degree comprise the remaining $3 \%$ of those who are registered.

\section{Sectoral changes}

For the most part, employers are seeking simple workers without any special qualifications. This is related to the majority of registered job-seekers having no special qualifications or special skills.

However, there has recently been an increase in the technology and communications sector (mostly in call centres), the health sector and the handcraft sector such as textiles, wood, paper, etc. It has been noticed that, during 2010, there was an increase of $4 \%$ in requests for specialists with higher education, and of $2 \%$ for those with a university education, compared to the previous year.

Public employment offices have offered $30-40 \%$ new jobs, differing according to region. The rest reflected replacements for existing jobs or seasonal work, in the fields of tourism, food processing or the building industry. New job offers were mostly in new private telecommunications companies (mobile companies, especially in Tiranë), telemarketing companies and mineral extraction. Replacements were related to the processing industry, where there is an regular turnover of staff from one enterprise to 
another. Seasonal offers were related to the building industry, food processing and tourism.

During 2009, public employment offices included in the unemployment payment scheme around 10000 unemployed people, $71 \%$ of whom had come from the private sector and $29 \%$ from the public sector. Unemployment in the private sector was related to the consequences of the global financial crisis. For example, in Shkodra entry into the public unemployment payment scheme for the first half of 2009 was $48 \%$, mostly from the clothing industry. In the second period of 2009, there was also an increase as a result of the privatisations of ARMO and ALBPETROL (both state oil companies).

Entry into the scheme from the public sector came mostly from the education sector; the energy sector, KESH (the Albanian Energy Company, a state-owned company, which has sold its distribution arm, leaving the other two arms state-owned); and the health sector.

The public sector continues to have a fall in employment, which appears as an outcome of the privatisation, or restructuring, of different parts of the public system. Meanwhile, the private non-agricultural sector saw the biggest increase during 2009 and 2010. The increase was most noticeable in small- and medium-sized enterprises.

\section{Gender equality}

Enhancing governmental mechanisms at central and local level, with a view to implementing and monitoring the wider strategy, brought about the setting up of the National Council of Gender Equality.

Order No. 3, dated 08/01/2009, had outlined the need to establish the Council and also determined its sphere of influence as an advisory authority for the management, determination and development of policies on gender equality in society. A Technical Secretariat for monitoring the gender equality national strategy was also established. This required changes within the Ministry of Labour.

Approval of law No. 9970, dated 24/07/2008 On gender equality also imposed an institutional gender equality obligation as regards the appointment of employees along ministry lines and local employers. Currently, efforts are focused on institutionalising this framework at municipality level.

Capacities should be established with regard to the creation of gender-related contact points at local level. Enhancing the capacities of these contact points was supported by an Austrian government project Equality in governance which provided training on gender issues. In 2009, training was conducted at basic level with representatives of local government in 38 municipalities of the country, through which some 672 people were trained.

There have been proposals from the Ministry's Gender Directorate to incorporate elements of gender equality into the framework for the process of the revision of the Labour Code. The work group has considered the incorporation of provisions on parental leave (birth leave for fathers); other proposals were made on flexible hours for employees assuming family responsibilities and on sexual harassment in the workplace.

Additionally, other proposals have been made to the draft law On safety and health at work in connection with vulnerable groups, encompassing special protection for 
pregnant women, women who have recently given birth and breastfeeding mothers in compliance with Directive No. 92/85CE.

Increasing public awareness on gender-related issues and domestic violence, and enhancing inter-institutional co-operation with civil society and all stakeholders concerning the integration of gender-related issues in all government policies at all levels, has been of great importance. The awareness campaign Women's rights are human rights in connection with national and international legislation has been launched, while different publications have been published on gender equality, such as explanatory handbooks, training handbooks on gender neutral legislation and periodical bulletins in Albanian and in English On an equal society without violence.

\section{Education policy}

The transformation that brought about the birth of the market economy has uncovered a need for other levels of qualifications and skills regarding new technologies and new kinds of services. Market and greater practical orientation are now targets that need to be achieved through the development of education and occupational training.

However, the education and occupational training system is weak: on the one hand with regard to quantity; and, on the other, with regard to quality. There is a lack of an appropriate infrastructure, insufficient financing, a low supply of human resources, ancient curricula and an out-of-date management style. Actually there are forty technical and occupationally-oriented schools in existence, spread throughout 22 regions. Only three of these schools are oriented towards agriculture and agribusiness.

The liberalisation of the licensing of private institutions in higher education and academic freedom was one of the main decisions taken by the government after 2005 . The strategy of the education system needs to be focused on the practical needs of the country for increasing the skills and training of young people, while reviewing curricula is one part of education reform in general.

\section{Active and passive labour market policies}

\section{Active policies}

The strategic employment objectives of the Ministry of Labour in the field of employment and professional training for the three-year period between 2010 and 2012 are focused on the need to establish a modern and unique system of employment services for the entire country. This is to be achieved by:

- boosting the performance of the employment services, specifically as regards the facilitation of employment, adjusting appropriately employment supply and demand

- reviewing the structure of employment offices, giving priority to specialists dealing with employment services

- establishing co-operation at regional and local levels focused on young people and people from specific groups encountering problems entering the labour market

- focusing on new labour market programmes specifically for separate groups such as people with disabilities, the long-term unemployed, etc. 
- unifying the employment services and raising the level of the skills of specialists in interpersonal relations with clients

- providing further training to specialists providing services to clients

- further improving the monitoring and evaluation of the employment services

- enhancing the quality of short-term labour market surveys carried out each year

- conducting employment fairs in all towns across the country.

Establishing and developing partnership relations with other stakeholders in the labour market is also necessary, while the Ministry needs also to establish a labour market information database. It has extensive plans to provide for the further development of its employment services staff to enhance their level of performance.

\section{Passive programmes}

Passive policies include ensuring incomes for people who are unemployed (as well as supporting participants in courses, especially the long-term unemployed).

Starting from 1 May 2009, the basic level of unemployment allowance was increased by $6 \%$, thus from 5980 Lek per month it was raised to 6300 Lek. With additional benefits on top, in accordance with the decision of the Council of Ministers, the compensation granted to each beneficiary remained at an average level of 8300 Lek per month.

The level of the unemployment allowance must be raised by $10-20 \%$ per year in order to reach ILO Convention No. 168 on Employment promotion and protection against unemployment and reach a level of $50 \%$ of the minimum nationwide salary. At the same time, there should be a reduction in the number of recipients of unemployment allowance, as a consequence of their gaining employment as a result of their participation in active programmes, of between 10 and $15 \%$ per year on average.

There needs to be greater co-operation between the institutions, the Labour Inspectorate, the Institute of Social Insurance and the General Directorate of Taxation, and the National Employment Service regarding all the problems connected to the functioning of the labour market, and not least concerning the addressing of the problems associated with the development of the informal economy.

Social insurance system

There needs to be further growth in the financial sustainability of the social insurance system. Proceeds from contributions are foreseen to grow at an annual average of $12-15 \%$ so that, in 2013 , compared to 2009 , revenues should be around $50 \%$ higher, while expenditures are foreseen to grow at an annual average of 8-10\% so that, in 2013 , they would be $35 \%$ higher than in 2009. In this way, the self-sustainability of the social insurance system will be increased, leading to a cut in the essential subsidies from the state budget.

Within the social insurance system, the pensions system is one that needs particular attention. The policies of raising pensions, as an important and indispensable element of social protection, needs to continue, with an average increase of $10 \%$. Relying also on the forecasts of the medium-term budget for 2010-2012, the increase in pensions for 2010-2012 has been envisaged as $6 \%$ in urban areas (7\% in 2010) and $15 \%$ in 
rural ones. The differentiated growth in pensions between urban and rural areas is with a view to attaining the objective of approximating the pensions system between both. At the same time, both the contributions of farmers and the subsidies from the state budget to cover these should continue so that those retiring in 2013 do so under the same circumstances as pensioners in urban areas.

Raising pensions and cutting the extent of social insurance contributions for 2009 was an important step. In 2009, the minimum monthly income of pensioners amounted to 12227 Lek in towns and 7130 Lek in villages - an increase of more than $46 \%$ for pensioners in towns and over $98 \%$ for pensioners in villages, compared to 2005 . This level of increase completely wipes out the negative effects of inflation on pensions, provides a real addition to the pensions of urban dwellers and implements the government's aim that low pensions grow at a quicker pace. This increase benefited 371000 rural pensioners and 150000 urban pensioners.

Starting from 1 May 2009, employers' social insurance contributions have been cut by five points, dropping down to $24.5 \%$. The cutting of the rate of these contributions has had an important impact on reducing the level of informality and might also assist the growth in the number of contributors as well as the raising of contributions-based revenues.

\section{Public employment services}

One means of the promotion of employment is the creation of active policies to support full-time employment, productively and freely chosen by citizens. To this end, the state has established, and continues to develop, employment offices which operate under a central authority.

The National Employment Service (NES) is an autonomous public employment service with the status of a central state administration. Its activities are ruled by the law on the promotion of employment. The NES is composed of 36 employment offices, twelve being regional and 24 local, with a total staffing complement of 372 people. The structure of the NES and its competencies are stipulated and approved by a decision of the Council of Ministers No. 42 on 17 January 1998, as modified by decisions No. 263 of 25 May 2000 and No. 17 of 10 January 2003.

The National Employment Service focuses on employment mediation services for job-seekers that are registered under the unemployment payment scheme, but also those who want to change their job, people with disabilities and employers. It offers professional consultative services to increase skills and promote self-employment. It manages the public funds approved by the government and public schemes, and takes payments in respect of unemployed clients registered on its database. It is responsible for financing employers who respond to different calls regarding proposals or projects for opening new jobs, or employing young people or those who have graduated from universities. It co-operates with local governments to develop public works through employing public services clients, encouraging employers to employ people with disabilities. It also offers professional training and retraining for job-seekers and young people between high school and university, and credits companies who train and retrain their employees. It is also responsible for data collection and statistics, studies and research into the labour market situation. 
Within the NES there are also services related to occupational training and orientation, as well as the practices of labour clubs and emigration offices. The NES has sent for training in the public occupational training centres some $65 \%$ of the total number of those who were registered as unemployed in 2010. The method of labour clubs seeks to increase the employment capabilities of each member, a method which was tested in one of the regions in the south-west of the country. The result was that $19 \%$ were employed in construction, out of 100 people who were trained when $70 \%$ were more than 45 years old and had only an elementary level education.

The emigration offices deal, on the one hand, with returned migrants intending to start new businesses in Albania after gaining experience in other countries; and, on the other, with returned Albanian migrants who want to be employed in the country. In 2010,650 returned migrants were officially registered as job-seekers, $52 \%$ being aged $25-40$ and $42 \%$ of them with only elementary education. Ten percent of them have found a job as a result of the mediation of the employment service.

\section{Equality on the labour market}

Data has suggested that women are not sufficiently encouraged to enter the labour market and, as a consequence, are less active in searching for a job. The Labour Code of 1995 and the Law on Gender Equality of 2004 called for equal treatment between men and women but, on average, women's incomes were lower than those of men, as well as the percentage level of their participation in the labour market.

In fact, specific policies included in the Employment Sector Strategy did reflect a commitment to equality and non-discrimination in favour of groups in need (women included); however, these need to be enforced efficiently and accompanied by an allocated specific budget such as, for instance, specific assistance as regards the training and employment of given groups in need; and the reduction of tariffs for specific groups that have been excluded from the labour market.

There are still groups that need to be taken into consideration: young people; victims of trafficking; former prisoner; Roma; and Egyptian women.

\section{Social dialogue}

Social dialogue in Albania consists of tripartite institutions. The three partners involved in the social dialogue are the state, as mediator and regulator, trade union organisations, and employer organisations. The social dialogue is regulated by law, as stipulated in the Labour Code. The main institution is the National Labour Council, an institution which has functioned since 1996 as a result of the first labour code following the democratic developments of the 1990s. The National Labour Council is composed of seven ministers from the government, seven members of the most representative trade unions and seven members of the most representative employer organisations.

Pessimistic conclusions may be expected, considering that the government has had eleven labour ministers in as many years. This reflects the very fragile political situation in the country which has sometimes ended in very serious, even terrible, events.

The operation of the National Labour Council has, nevertheless, shown some positive results. For example, it has enabled the social partners to gain legitimacy and to 
exert a degree of influence on economic and social policies - particularly in the area of income and wage policies, albeit prior to 2006.

However, it has also shown some administrative weaknesses and primarily, perhaps, concerning the irregularity of its meetings. The Council's Constitution requires at least four meetings per year, but it has often been convened much less frequently the longest period without a meeting was sixteen months. The anomic functioning of its tripartite commissions is another administrative weak point. A lack of partnership and social dialogue in the different fields of the economy and at local levels is another negative sign, as was the Council never having had financial independence, the real foundation for true institutional independence.

Workers and employers believe that the National Labour Council has not been heard properly in the discussion of serious and important problems in economic life. For example, the Council's opinion was not sought when a major socio-economic development and poverty reduction strategy was on the government's agenda. The opinion of workers has not been considered during the course of privatisation in general, or strategic privatisation in particular. At times, a discussion of the state budget has not involved the social partners.

Workers and employers were, therefore, not satisfied with the functioning of the National Labour Council and they did request the ILO's assistance in reviewing the basis of its operation. This began with a revision of the Labour Code, where the ILO offered very specialised input, making comments on the draft legislation. The ILO's contribution was taken into consideration and incorporated into the final draft submitted to Parliament, leading to the new Labour Code being passed by Parliament in July 2003.

The technical tripartite committees, composed of the technical representatives of government, trade unions and employers, are not functioning as required. Nominally, they have had some formal meetings, although not regularly before the general meetings of the National Labour Council. Usually, the decisions that are taken by the government are not the result of any changes or suggestions of the technical committees, or even of the National Labour Council itself.

For many years, there has been a proposal from the trade unions and the organisation of employers to establish an Economic and Social Council, which would have an extended area of discussion for many more issues related to government policies, but the proposal has still not been taken into consideration by the government.

No data regarding the activity of the National Labour Council from 2006 up to 2010 exist in the database of the Ministry of Labour and Social Affairs and Equal Opportunities.

The social dialogue is also institutionalised in other institutions, such as the National Employment Service and the Social Insurance Institute. The representatives of trade unions and employer organisations are members of the tripartite commissions of the regional employment offices for the employment projects which are proposed by private companies and sponsored by the state employment funds. These commissions are formally involved in the process. In addition, trade unions and employer organisations represent their interests on the executive board of the Social Insurance Institute, which is now a part of the Ministry of Finance. 
According to the amendments to the Labour Code in 2003, a great many procedures are stipulated for social dialogue in the case of labour conflict or disputes, or even strikes. Officially, however, there are no records which can show the involvement of the social partners in developments on the labour market or in the activity of the National Labour Council, as the legally-oriented institution to engage in labour disputes.

\section{Migration}

Albania has approved strategies in this area which are under implementation. These strategies have the intention of ensuring social protection for groups in need, including Albanians who have returned from abroad. The institutional framework for managing migration issues also covers the return and re-integration issues of Albanians.

The institutions related to migration issues which have a stakeholder role are as follows:

- Ministry of Labour, which is one of the main ministries responsible for drafting migration policies and implementing them through their structures, and which encompasses the Directorate of Policies for Migration, Return and Re-integration, which is directly involved in the preparation and implementation of migration policies

- Directorate of Policies for Employment and Professional Training, which prepares active and passive programmes for employment and occupational training, including for returning Albanians who need orientation and occupational training

- National Employment Service which operates, through its employment offices, support for returning Albanians as regards information and orientation concerning the labour market

- State Social Service, which is involved in the implementation of policies and legislation for social services (this structure is part of the national mechanism to identify victims of human trafficking)

- Ministry of Foreign Affairs, which co-ordinates bilateral and multilateral negotiations between Albania and other countries, including repatriation agreements and emigration for employment purposes

- Ministry of the Interior, which is one of the main players in the management of migration within the country, including as regards the entrance, stay, transit and exit from the Republic of Albania and the implementation of re-acceptance agreements

- Border and Migration Police Department of the State Police, which is responsible for the implementation of re-acceptance agreements via interviewing and identifying the victims of human trafficking; or otherwise foreigners who have crossed to the EU area illegally through Albanian territory.

All these offer necessary assistance and even take care of transportation to nearby urban centres.

The National Co-ordinator against Human Trafficking manages and monitors the entire national mechanism concerning human trafficking and unaccompanied minors. Additionally, the Ministry of Education and Science is responsible for the education of Albanians living abroad and for facilitating their access to education opportunities inside the country, such as validating the diplomas of students studying abroad so that 
they can be registered in the country's education system. Furthermore, the Directorate of Local Government and Decentralisation is responsible for the registration of the population, including for the children of emigrants born abroad, while the Ministry of Economy, Trade and Energy invites Albanians living abroad to invest in their native country.

Another service offered by the migration department concerns work permits for foreigners. Some 1839 people have been given work permits, with just over one-third requested by either Turkish, Chinese, Greek and Italian citizens. Within this percentage, $45 \%$ were Chinese, $39 \%$ Turkish, $8 \%$ Greek and $7 \%$ Italian.

The highest percentage of work permits comprises employees. The activities which are most in demand for work permits are: $14 \%$ in the building industry; $13 \%$ in services; $12 \%$ in trade; etc. In total, 1226 work permits have been approved across all the regional employment offices.

\section{Conclusions}

Trends in unemployment from the Albanian Institute of Statistics (INSTAT) showed that, at the end of 2010 , the unemployment level was $13.5 \%$ or $0.3 \%$ lower than in 2009. The unemployment database showed that 143000 people were unemployed. If we compare the trends of employment for 2010, we see that unemployment fell when employment rose.

During 2011, 51687 new job-seekers were registered. The NES database shows that the newcomers are largely between 20 and 24 years of age. An increase in the number of job-seekers with higher education and who are over 45 years old was also noticed. The latter group has registered as job-seekers so as to benefit from unemployed status and, therefore, to gain from the health insurance payment scheme.

On the other hand, 53692 people left the unemployment payment scheme, whereby $23 \%$ have become employed; $7 \%$ have gone on training courses; and $2 \%$ were involved in employment promotion programmes. The remainder have been deleted from the unemployment list because they have not periodically presented themselves, according to the specific legal obligations that, therefore, have not been respected.

Governments need to be focused on the implementation of reforms in employment, education and occupational training.

There is also a need for better co-ordination between public institutions with regard to identifying illegal work.

It is necessary that the public employment service should have the appropriate infrastructure, staff and methods to promote the employment of job-seekers and businesses.

It is strongly recommended that existing policies and strategies should actually be implemented, rather than changing these for new ones.

The system of new curricula in education and occupational training needs to be finished and implemented as quickly as possible.

The different policies need to be co-ordinated and continually monitored by specialised structures. 


\section{References}

Albanian Institute of Statistics Labour Force Survey (LFS) 2007-2008.

Albanian Institute of Statistics Labour Force Survey 2009.

Economic and Fiscal Programme 2010-2012.

ILO (2010) Analysis of the youth labour market in Albania International Labour Organization.

Ministry of Education and Science National Education Strategy 2004-2015.

Ministry of Finance Public Finance Sector Strategy.

Ministry of Labour, Social Affairs and Equal Opportunities Sectoral Strategy on Employment and Vocational Training 2007-2013.

Ministry of Labour, Social Affairs and Equal Opportunities Strategy for Social Inclusion 2007-2013

National Strategy for Migration.

World Bank (2007) Albania Country Brief. 